\title{
PENGOLAHAN ES KRIM DAUN KELOR SEBAGAI PENGUATAN EKONOMI MASYARAKAT SAAT PANDEMI COVID-19 DI DESA BOJONGMENGGER KECAMATAN CIJEUNGJING KABUPATEN CIAMIS
}

\section{PROCESSING OF MORINGA LEAF ICE CREAM AS STRENGHTHENING THE COMMUNITY'S ECONOMY DURING THE COVID -19 PANDEMIC IN BOJONGMENGGER CIJEUNGJING CIAMIS}

\author{
Nina Herlina*, Lia Yulia \\ Universitas Galuh, Ciamis, Indonesia \\ E-mail: nitatamasampurna@gmail.com \\ (Diterima 05-05-2021; Disetujui 05-08-2021)
}

\begin{abstract}
ABSTRAK
Es krim merupakan salah satu produk olahan susu yang dibuat melalui proses pembekuan dan agitasi. Prinsipnya adalah membentuk rongga udara pada campuran bahan es krim. Es krim bukan makanan yang baru, namun saat ini keberadaan es krim sudah menjadi jajanan yang banyak dicari oleh masyarakat, baik oleh anak-anak maupun dewasa. Namun, pada kenyataannya es krim tersebut banyak yang mengandung bahan pengawet karena diproduksi secara masal oleh suatu pabrik sehingga berbahaya bagi tubuh manusia. Oleh karena itu, dilakukan inovasi supaya es krim menjadi makanan sehat yang digemari semua kalangan. Dengan menggunakan daun kelor berusaha menciptakan es krim yang sehat dan bergizi. Pengolahan yang dilakukan yaitu dengan menambahkan campuran daun kelor dan berbagai topping pada es krim tersebut. Varian ini dibuat beragam agar masyarakat penyuka es krim memiliki beragam pilihan dan tidak membosankan. Bahan dasar yang digunakan dalam pembuatan es krim adalah kombinasi susu dengan bahan tambahan seperti gula tanpa bahan perasa dan warna, dan stabilizer. Bahan campuran es krim disebut ice cream mix (ICM), dengan pencampuran bahan yang tepat dan pengolahan yang benar maka dapat dihasilkan es krim dengan kualitas baik.
\end{abstract}

Kata Kunci : daun kelor, penguatan ekonomi

\begin{abstract}
Ice cream is a dairy product that is made through a process of freezing and agitation. The principle is to form air cavities in the ice cream mixture. Ice cream is not a new food, but now the existence of ice cream has become a domination that is much sought after by the public, both children and adults. But in fact, many of these ice creams contain preservatives because they are mass produced by a factory so they are harmful to the human body. Therefore, innovations are made so that ice cream becomes a healthy food that is popular with all groups. By using Moringa leaves trying to create a healthy and nutritious ice cream. The processing is done by adding a mixture of Moringa leaves and various toppings to the ice cream. These variants are made various so that people who like ice cream have a variety of choices and are not boring. The basic ingredients used in making ice cream are a combination of milk with additional ingredients such as sugar without flavor and color, and stabilizers. Ice cream mixture is called ice cream mix (ICM), with the right mixing of ingredients and the correct processing it can produce ice cream with good quality.
\end{abstract}

Keywords: Moringa leaves, economic strengthening

\section{PENDAHULUAN}

Ciamis merupakan daerah tropis yang banyak ditumbuhi pohon kelor. Bahkan tahun 2015 Bupati Ciamis yang saat itu dijabat oleh Bapak Iing Syam Arifin telah mencanangkan penanaman pohon kelor di masyarakat se-Kabupaten Ciamis. Setiap bagian pohon kelor sangat bermanfaat bagi kesehatan manusia, daunnya, batangnya dan akarnya. Daunnya 
Pengolahan Es Krim Daun Kelor Sebagai Penguatan Ekonomi Masyarakat Saat Pandemi Covid-19 di Desa Bojongmengger Kecamatan Cijeungjing Kabupaten Ciamis

Nina Herlina, Yulia

selain bisa dimasak untuk sayur juga bisa dibuat untuk teh. Demikian juga batangnya dan akarnya bisa dimanfaatkan untuk obat herbal.

Dalam usulan pengabdian ini digunakan daun kelor sebagai campuran pembuatan es krim. Es krim merupakan salah satu jenis makanan yang sangat digemari oleh semua kalangan. Popularitas es krim semakin meningkat di negara-negara yang beriklim tropis atau panas seperti di Indonesia. Konsumsi es krim di Indonesia diperkirakan semakin meningkat seiring dengan semakin banyaknya masyarakat yang menyukai es krim bahkan di Indonesia semakin bermunculan pedagang-pedagang es krim yang mengadopsi produk luar negeri, sehingga mengakibatkan pergeseran cita rasa masyarakat tradisonal perlahanlahan kurang diminati atau bahkan ditinggalkan.

Hanya sedikit para pelaku bisnis kuliner mengusung tema makanan unik dalam bisnisnya apalagi dengan menggunakan bahan dasar tradisional dari negeri sendiri. Dari hasil analisis tersebut maka timbullah ide untuk membuat olahan makanan es krim berbasis inovasi baru dari daun kelor, yaitu es krim daun kelor.

Es krim merupakan salah satu produk olahan susu yang dibuat melalui proses pembekuan dan agitasi. Prinsipnya adalah membentuk rongga udara pada campuran bahan es krim. Es krim bukan makanan yang baru, namun saat ini keberadaan es krim sudah menjadi jajanan yang banyak dicari oleh masyarakat baik oleh anak-anak maupun dewasa.

Namun, pada kenyataannya es krim tersebut banyak yang mengandung bahan pengawet karena diproduksi secara masal oleh suatu pabrik sehingga berbahaya bagi tubuh manusia. Oleh karena itu, dilakukan inovasi supaya es krim menjadi makanan sehat yang digemari semua kalangan. Dengan menggunakan daun kelor berusaha menciptakan es krim yang sehat dan bergizi. Pengolahan yang dilakukan yaitu dengan menambahkan campuran daun kelor dan berbagai topping pada es krim tersebut. Varian ini dibuat beragam agar masyarakat penyuka es krim memiliki beragam pilihan dan tidak membosankan. Bahan dasar yang digunakan dalam pembuatan es krim adalah kombinasi susu dengan bahan tambahan seperti gula tanpa bahan perasa dan warna, dan stabilizer. Bahan campuran es krim disebut ice cream mix (ICM), dengan pencampuran bahan yang tepat dan pengolahan yang benar maka dapat dihasilkan es krim dengan kualitas baik.

Berdasarkan latar belakang dan analisis situasi di atas, maka permasalahan yang dikemukakan adalah:

1. Bagaimana pengolahan pangan es krim yang berasal dari daun kelor sebagai inovasi makanan bergizi tinggi. 
2. Bagaimana memasyarakatkan pengolahan es krim daun kelor agar disukai oleh semua kalangan masyarakat Ciamis

Berdasarkan permasalahan di atas, maka kegiatan pengabdian pengolahan daun kelor ini bertujuan untuk:

1. Membuat pengolahan pangan es krim yang berasal dari daun kelor sebagai inovasi makanan bergizi tinggi.

2. Memasyarakatkan pengolahan es krim daun kelor agar disukai oleh semua kalangan masyarakat Indonesia.

\section{BAHAN DAN METODE}

Adapun peralatan dan bahan yang harus disiapkan untuk pembuatan es krim daun kelor yaitu

1. Alat
a. Pisau
b. Panci
c. Wajan
d. Spatula/pengaduk
e. Gelas ukur
f. Sendok
g. Baskom/ mangkuk
h. Lemari es
i. Timbangan
j. Blender
k. Saringan
1. Kamera
m. Alat tulis
n. Cup atau mangkuk tertutup untuk es krim yang sudah jadi
o. Termometer

2. Bahan
a. Daun kelor
b. Susu kedelai atau susu sapi atau susu skim
c. Whipping cream/TBM
d. Gula pasir
e. Es batu 
Pengolahan Es Krim Daun Kelor Sebagai Penguatan Ekonomi Masyarakat Saat Pandemi Covid-19 di Desa Bojongmengger Kecamatan Cijeungjing Kabupaten Ciamis

Nina Herlina, Yulia

Permasalahan utama berkaitan dengan masalah ini adalah:

1. Kurangnya pengetahuan masyarakat dalam pemanfaatan daun kelor sebagai sumber bahan makanan ataupun sebagai obat herbal. Apalagi masyarakat belom tahu pemanfaatan daun kelor sebagai bahan campuran es krim.

2. Kurangnya wawasan tentang es krim daun kelor yang dibuat dengan campuran daun kelor, sehingga perlu dimasyarakatkan bahwa es krim rasa daun kelor tidak kalah enaknya dengan rasa es krim yang dibuat kekinian.

Usulan pemecahan yang bersifat operasional dalam kegiatan pengabdian ini adalah sebagai berikut:

1. Memberikan penyuluhan, pendidikan dan pelatihan untuk meningkatkan pengetahuan masyarakat dalam pemanfaatan daun kelor sebagai sumber bahan makanan ataupun sebagai obat herbal. Apalagi masyarakat belom tahu pemanfaatan daun kelor sebagai bahan campuran es krim.

2. Memberikan wawasan tentang es krim daun kelor yang dibuat dengan campuran daun kelor, sehingga perlu dimasyarakatkan bahwa es krim rasa daun kelor tidak kalah enaknya dengan rasa es krim yang dibuat kekinian. Hasil pengolahan es krim daun kelor ini selayaknya dirasakan oleh masyarakat agar mencintai makanan olahan local.

\section{Langkah-langkah Pelaksanaan}

Pelaksanaan kegiatan pengabdian pada masyarakat ini dilakukan dengan menggunakan metode ceramah, tutorial, diskusi dan praktek. Adapun tahapan pelaksanaan kegiatan pengabdian ini adalah sebagai berikut:

1. Langkah 1 (Metode Ceramah):

Peserta diberikan wawasan mengenai pentingnya pemanfaatan daun kelor dan cara pengolahan daun kelor sebagai tambahan pembuatan es krim. Sehingga masyarakat mengetahui bahwa es krim dengan campuran daun kelor tidak kalah enaknya dengan es krim kekinian yang beredar saat ini. Langkah pertama dengan metode ceramah ini dilakukan selama 1,5 jam.

2. Langkah 2 (Metode Tutorial):

Peserta pelatihan pengolahan es krim daun kelor diberikan materi tentang peningkatan nilai tambah dan nilai guna dari daun kelor. Kemudian diberi penjelasan tentang langkah-langkah persiapan untuk pengolahan es krim daun kelor. Materi ini disampaikan dalam bentuk tutorial disertai dengan latihan pengolahan daun kelor. Langkah kedua diselenggarakan selama 1,5 jam. 
3. Langkah 3 (Metode Diskusi):

Peserta pelatihan diberikan kesempatan untuk mendiskusikan permasalahan atau persiapan yang berkaitan dengan pengolahan daun kelor. Peserta juga mempersiapkan bahan-bahan yang lainnya untuk pembuatan es krim daun kelor. Langkah ketiga diselenggarakan selama 1 jam.

4. Langkah 4 (Praktek)

Pengolahan daun kelor menjadi bahan dasar es krim ini merupakan pengolahan bahan pangan nabati yang belum banyak dibuat dan belum ada di pasaran. Sehingga dalam proses pembuatannya masih di kalangan keluarga atau lingkungan terdekat. Para peserta harus mengimplementasikan dari hasil penyuluhan dan tutorial cara-cara pengolahan es krim daun kelor.

Kegiatan pengabdian dilaksanakan dalam jangka waktu 2 bulan. Jadwal kegiatan pengabdian disusun mulai dari penyusunan proposal sampai dengan tahap pelaporan hasil kegiatan pengabdian.

1. Penyusunan proposal kegiatan dilakukan sebagai tahap pertama pengajuan program pengabdian masyarakat.

2. Persiapan pelatihan yang dilakukan meliputi pengumpulan dan penyusunan materimateri pelatihan.

3. Pelatihan yang akan dilakukan meliputi metode ceramah, tutorial, diskusi dan dilanjutkan dengan kegiatan praktek atau pendampingan.

4. Pelaporan hasil kegiatan dilakukan sebagai bentuk pertanggungjawaban atas kegiatan.

\section{HASIL DAN PEMBAHASAN}

Pelatihan pengolahan es krim daun kelor dilaksanakan bersama mitra pengabdian di Desa Bojongmengger, yaitu Tim Penggerak PKK Desa Bojongmengger. Jumlah peserta pelatihan sebanyak 20 orang yang terdiri atas perwakilan PKK setiap dusun beserta pengurus PKK tingkat desa.

Persiapan yang dilakukan adalah menyediakan bahan-bahan dan peralatan yang dibutuhkan pada saat pelatihan. Pelaksanaan pelatihan bertempat di Aula Balai Desa Bojongmengger dengan memperhatikan protokol kesehatan, sehingga peserta dibatasi hanya 20 orang, walaupun anggota Tim Penggerak PKK Desa Bojongmengger lebih banyak jumlahnya. Metode yang digunakan terlebih dahulu menggunakan ceramah dengan materi cara pengolahan es krim daun kelor. Apabila bahan dan alat-alat sudah siap maka segera melakukan kegiatan pembuatan es krim. 
Pengolahan Es Krim Daun Kelor Sebagai Penguatan Ekonomi Masyarakat Saat Pandemi Covid-19 di Desa Bojongmengger Kecamatan Cijeungjing Kabupaten Ciamis

Nina Herlina, Yulia

a. Metode selanjutnya yaitu praktek, sehingga materi yang sudah disampaikan melalui ceramah langsung dipraktekan. Daun kelor yang digunakan bisa daun kelor segar yag baru dipetik atau tepung daun kelor yang sdah dikeringkan. Apabila daun kelor segar maka daun kelor yang masih muda dipetik dari tangkai daun pertama sampai tangkai daun ketujuh yang masih hijau selanjutnya daun kelor tersebut dicuci dengan air bersih lalu dipetik dari tangkai daunnya, kemudian nanti sekaligus diblender dengan bahanbahan yang lain.

b. Apabila daun kelor dikeringkan maka harus dibuat dulu menjadi tepung daun kelor. Pembuatan tepung dari daun kelor kering sering digunakan blender kering dan diayak dengan ayakan 100 mash untuk memisahkan batang-batang kecil yang tidak bisa hancur dengan blender, selanjutnya disimpan dalam wadah plastik yang kedap udara (Zakaria et al., 2012).

c. Selanjutnya bahan-bahan yang sudah disiapkan tadi diblender sekaligus sekitar 20 menit atau sampai campuran bahan es krim mengembang dan lembut. Setelah adonan es krim tercampur secara merata maka adonan siap untuk dimasukkan ke dalam cup es krim, selanjutnya cup es krim yang sudah diisi langsung dimasukkan ke dalam freezer.

d. Es krim bisa dihidangkan dan dinikmati setelah cup es krim di dalam freezer kira-kira 2 jam, maka es krim dengan aroma dan rasa daun kelor akan terasa nikmat dan mempunyai varian rasa yang selama ini tidak ada di pasaran.

Dengan dilaksanakannya kegiatan pengabdian terhadap masyarakat yaitu pengolahan es krim daun kelor dengan mitra kegiatan Tim Penggerak PKK di Desa Bojongmengger Kecamatan Cijeungjing, maka diharapkan dapat membantu masyarakat Desa Bojongmengger memanfaatkan daun kelor untuk pembuatan es krim sebagai vaarian rasa es krim yang tidak ditemukan di pasaran. Sehingga daun kelor yang banyak tersebar di masyarakat bisa dimanfaatkan sebagai bahan baku pembuatan es krim yang diproduksi di rumah.

Bahkan apabila pengolahan es krim daun kelor ini menjadi industri rumahan maka masyarakat akan memperoleh penghasilan sehingga pemberdayaan dan pemanfaatan daun kelor ini dapat menanggulangi kemiskinan.

Hasil dari evaluasi kegiatan pengabdian ini sangat membanggakan karena di awal tahun 2021 para pengurus Tim Penggerak PKK di Desa Bojongmengger telah memahami dan terampil dalam pembuatan es krim daun kelor. Masyarakat juga sudah bisa menghasilkan uang hasil dari menjual produk es krim di rumah. 


\section{KESIMPULAN DAN SARAN}

Pelaksanaan kegiatan pengabdian diharapkan dapat membantu masyarakat Desa Bojongmengger dalam memanfaatkan daun kelor untuk pembuatan es krim sebagai varian rasa es krim yang tidak ditemukan di pasaran. Sehingga daun kelor yang banyak tersebar di masyarakat bisa dimanfaatkan sebagai bahan baku pembuatan es krim yang diproduksi di rumah.

Hasil dari evaluasi kegiatan pengabdian ini sangat membanggakan karena di awal tahun 2021 para pengurus Tim Penggerak PKK Di Desa Bojongmengger telah memahami dan terampil dalam pembuatan es krim daun kelor. Masyarakat juga sudah bisa menghasilkan uang hasil dari menjual produk es krim di rumah.

\section{DAFTAR PUSTAKA}

Adimidjaya, Linda, F. dan Pulu, H. 2011, Lima Belas Resep Es Krim. Favourite. Jakarta: PT. Gaya Favourite Press

Chan, S. 2003. Relationship marketing: Inovasi pemasaran yang membuat pelanggan bertekuk lutut. Jakarta: PT. Gramedia Pustaka Utama.

Padaga dan Sawitri. 2006. Membuat es krim yang sehat. Surabaya: Trubus Agrisana.

Purnomo dan Andiono, 2007. Ilmu Pangan. Jakarta: Universitas Indonesia Press.

Simbolan, J.M dan Katharina, N . 2007. Cegah Malnutrisi dengan Kelor. Yogyakarta: Kanisius.

Susilorini, Tri Eko Manik Eirry Sawitri. 2007. Produk olahan susu. Depok Penebar Swadaya.

Suwahyono, 2008. Khasiat ajaib si pohon Ghaib: mengupas rahasia tersembunyi Pohon Kelor. Penerbit Andi.

Winarno. F.G. 2006. Kimia Pangan dan Gizi. Jakarta : PT. Gramedia Pustaka Utama.

Zakaria, Tamrin.A, Sirajuddin, Hartono. R. 2012. Penambahan daun kelor pada menu makanan sehari-hari dalam upaya penanggulangan gizi. Media Gizi Pangan 